\title{
Efektivitas Layanan Informasi dengan Pendekatan Role Playing untuk Meningkatkan Penyesuaian Sosial Siswa Kelas VII SMPN 3 Batusangkar \\ Yesi Aulia Fitri ${ }^{1}$, Firman Firman ${ }^{2}$, Yeni Karneli ${ }^{3}$
}

Email : firman@,konselor.org

\begin{abstract}
Abstrak: Dewasa ini ditemukan sebagian siswa kurang menyatu dengan siswa yang lain, ditunjukan oleh adanya kelompok-kelompok tertentu yang tidak bisa disatukan dengan kelompok lain, suka menyendiri, kurang tanggap serta memilih teman dalam bergaul. Layanan informasi untuk meningkatkan penyesuaian sosial siswa sudah diberikan oleh guru Bimbingan dan Konseling atau Konselor, namun belum mencapai sasaran sesuai yang diharapkan. Penelitian ini bertujuan untuk melihat efektivitas layanan informasi dengan pendekatan role playing dalam meningkatkan penyesuaian sosial siswa di sekolah.

Penelitian ini menggunakan pendekatan kuantitatif. Jenis penelitian ini termasuk penelitian dengan rancangan Quasy-Experiment jenis The Non Equivalent Control Group. Tempat penelitian ini SMPN 3 Batusangkar dengan subjek kelas VII. Instrumen yang digunakan yaitu kuesioner (angket) dengan skala likert. Data dianalisis dengan menggunakan T-test dan dengan bantuan program Statistical Product and Service Solution (SPSS) versi 20.

Temuan penelitian ini mengungkapkan bahwa: (1) terdapat perbedaan yang signifikan peningkatan penyesuaian sosial siswa sebelum dan sesudah mengikuti layanan informasi dengan pendekatan role playing pada kelompok eksperimen, (2) tidak terdapat perbedaan yang signifikan peningkatan penyesuaian sosial siswa sebelum dan sesudah mengikuti layanan informasi secara konvensional pada kelompok kontrol, (3) terdapat perbedaan yang signifikan peningkatan penyesuaian sosial siswa pada kelompok eksperimen dengan kelompok kontrol. Berdasarkan temuan di atas, dapat disimpulkan bahwa penyesuaian sosial siswa dapat ditingkatkan melalui layanan informasi dengan pendekatan role playing.
\end{abstract}

Kata Kunci: Layanan Informasi, Penyesuaian Sosial, Role Playing.

\section{PENDAHULUAN}

Remaja merupakan individu yang telah mengalami masa balig atau berfungsinya hormon reproduksi sehingga wanita mengalami menstruasi dan laki-laki mengalami mimpi basah. Masa remaja merupakan salah satu periode dalam rentangan kehidupan manusia, dimana dalam periode remaja ini menunjukkan individu telah meninggalkan masa anak-anaknya dan mulai memasuki masa dewasa atau yang biasa disebut dengan masa peralihan. Oleh karena itu periode remaja dapat dikatakan periode transisi dari masa anak-anak ke masa dewasa.

Pada masa remaja, seorang individu mulai mencoba menemukan jawaban dari pertanyaanpertanyaan yang muncul dari dalam dirinya. Pertanyaan tersebut adalah ungkapan dari sebuah proses pencarian identitas diri seorang remaja. Pada usia remaja, tugas perkembangan yang berkaitan dengan penyesuaian sosial merupakan tugas perkembangan yang paling sulit dipenuhi, karena mengandung resiko cukup berat, karena kegagalan dalam proses penyesuaian sosial pada usia remaja akan berdampak pada penyesuaian sosial ditahap perkembangan selanjutnya. Pernyataan di atas sesuai dengan pendapat Hurlock (1993:213) bahwa penyesuaian sosial merupakan salah satu tugas perkembangan pada masa remaja yang tersulit.

Remaja yang berkembang dengan baik adalah remaja yang tugas perkembangannya tercapai dengan sempurna. Kesempurnaan siswa dalam membina penyesuaian sosial tergambar dari siswa tersebut mampu berinteraksi yang baik dengan siapapun, memiliki pandangan yang positif pada orang lain, dan mampu menyesuaikan diri dengan orang lain.

\begin{tabular}{lcrr}
\multicolumn{4}{c}{ Kemampuan remaja dalam memenuhi } \\
tugas-tugas perkembangan sosial akan \\
mengantarkan & individu dalam & kemampuan
\end{tabular}

\footnotetext{
${ }^{1}$ Yesi Aulia Fitri(1), Jurusan Bimbingan dan Konseling, Fakultas Ilmu Pendidikan Universitas Negeri Padang

${ }^{2}$ Firman(2), Jurusan Bimbingan dan Konseling, Fakultas Ilmu Pendidikan Universitas Negeri Padang

${ }^{3}$ Yeni Karneli(3), Jurusan Bimbingan dan Konseling, Fakultas Ilmu Pendidikan Universitas Negeri Padang
} 
menyesuaikan diri di lingkungan sosial. Lebih lanjut remaja akan mencapai kehidupan yang harmonis ditengah-tengah lingkungan sosial. Oleh karena itu, keberhasilan remaja dalam memenuhi tugas-tugas perkembangan mestinya menjadi perhatian khusus.

Schneiders (1964:454) menjelaskan penyesuaian sosial merupakan cara yang dilakukan individu dalam menyelaraskan kebutuhan internal dengan kebutuhan eksternal yang tercermin dalam kemampuan menjalin relasi dengan orang lain, berpartisipasi dalam pergaulan, menunjukkan minat serta menunjukkan kepuasan dalam beraktivitas.

Penyesuaian sosial juga dapat dikatakan sebagai proses adaptasi bagi seorang individu dengan lingkungannya sehingga individu tersebut dapat diterima dan berada dalam lingkungan tersebut. Jika dikaitkan dengan siswa di sekolah, penyesuaian sosial diartikan sebagai proses adaptasi siswa dengan lingkungan di sekolahnya, baik dengan teman sebaya, guru, tata usaha serta lingkungan sekolah secara umum seperti bangunan fisik, tata tertib atau peraturan sekolah dan lainnya.

Biasanya orang yang berhasil melakukan penyesuaian sosial dengan baik mengembangkan sikap sosial yang menyenangkan, seperti kesediaan untuk membantu orang lain, meskipun mereka sendiri mengalami kesulitan, mereka tidak terkait pada diri sendiri.

Guru BK mempunyai tugas dan tanggung jawab membantu siswa dalam meningkatkan penyesuaian sosial, maka guru BK melaksanakan layanan bimbingan dan konseling di sekolah. Prayitno (2009: 26) berpendapat "Pelayanan konseling bertujuan menyiapkan kondisi pribadi yang mandiri, sukses, dan berkehidupan efektif dalam kesehariannya".

Kondisi-kondisi yang dimaksudkan itu tidak datang dengan sendirinya, melainkan melalui pengembangan yang terarah, yaitu melalui pendidikan yang di dalamnya terdapat pelayanan konseling. Salah satu layanan yang dilakukan guru BK di sekolah yaitu layanan informasi.Sebagaimana yang dikemukakan dikemukakan Prayitno (2006:266) bahwa: Secara umum layanan informasi memberikan pemahaman kepada individu-individu yang berkepentingan tentang berbagai hal yang diperlukan untuk menguasai suatu tugas atau kegiatan, atau untuk menentukan arah suatu tujuan atau rencana yang dikehendaki.

Dengan demikian layanan informasi merupakan layanan untuk membekali siswa dengan berbagai informasi yang diperlukan, berkenaan dengan bidang bimbingan pribadi, sosial, belajar dan karir. Dengan memperoleh informasi yang tepat dan memadai, siswa akan dapat mempertimbangkan berbagai alternatif pilihan, membuat rencana dan mengambil keputusan untuk kepentingan pribadi dalam merencanakan kehidupan sendiri.

Layanan informasi yang dimaksud adalah dengan menggunakan pendekatan role playing atau bermain peran, yang mana menurut Sudjana (dalam Istarani 2012:70) bermain peran merupakan suatu kegiatan pembelajaran yang menekankan pada kemampuan penampilan peserta didik untuk memerankan status dan fungsi pihak-pihak lain yang terdapat pada kehidupan nyata. Role playing bertujuan untuk membantu siswa menemukan makna diri (jati diri) di dunia sosial dan memecahkan dilema dengan bantuan kelompok. Artinya melalui role playing siswa belajar menggunakan konsep peran, menyadari adanya peran-peran yang berbeda dan memikirkan perilaku dirinya dan perilaku orang lain.

Berdasarkan hasil observasi pada hari kamis tanggal 21 Mei 2015 terdapat banyak siswa yang belum mampu melakukan penyesuaian sosial yang baik, seperti mereka sering membuat teman berkelompok-kelompok atau geng baik di dalam belajar maupun berteman, menunjukan persaingan yang tidak sehat sesama teman sebaya, misalnya mereka cenderung menyembunyikan informasi dari guru terhadap teman yang tidak hadir, menunjukkan perilaku acuh tak acuh terhadap teman, senang menyendiri, kurang tanggap apabila teman membutuhkan bantuan, tidak mau menanggapi pendapat teman, serta kurang aktif apabila bekerja kelompok dengan teman, memilihmilih teman di dalam bergaul. Siswa yang menunjukkan perilaku tersebut dikarenakan mereka cenderung masih merasa malu, takut dan bingung dalam menghadapi sekolah yang baru, sehingga mengalami kesulitan menyesuaikan diri dengan teman dan lingkungan. Hal tersebut dikarenakan siswa kelas VII merupakan siswa baru yang butuh penyesuaian sosial dengan keadaan sekolah yang berbeda dengan sekolah sebelumnya.

Selanjutnya pada pelaksanaan layanan informasi ditemukan bahwa guru BK kurang efektif dalam memberikan layanan informasi seperti guru BK tidak memberikan layanan informasi sesuai dengan program BK yang telah dibuat, siswa kurang tertarik pada materi yang diberikan oleh guru BK terlihat pada seringnya siswa keluar masuk pada saat jam pembelajaran berlangsung, terlihat siswa mengobrol saat layanan informasi berlangsung, dan guru BK tidak menggunakan 
metode atau media pembelajaran yang inovatif didalam memberikan layanan informasi.

Hal tersebut didukung oleh hasil penelitian Ahmad Yanizon (2012) diperoleh dari hasil pre-test tingkat penyesuaian sosial siswa di Madrasah Aliyah Negeri 1 Curup bahwa tidak ada siswa yang memiliki tingkat penyesuaian tinggi, $80 \%$ siswa memiliki penyesuaian sedang dan 20\% siswa memiliki tingkat penyesuaian rendah. Selanjutnya dari penelitian Nova Erianti (2011) menunjukkan bahwa $51,45 \%$ siswa mengalami masalah dalam menjunjung tinggi nilai-nilai sosial dalam berperilaku, $37,8 \%$ siswa bermasalah dalam membina keakraban, $33,57 \%$ siswa mengalami masalah dalam bekerja sama dengan teman sebaya, $36,32 \%$ siswa mengalami masalah dengan kontrol emosi seperti berpikir negatif serta menjelekjelekan teman, 44,34\% siswa mengalami masalah dengan bertingkah laku lemah lembut, ramah dan baik hati. Serta 33,6\% siswa bermasalah dalam bertoleransi.

Sementara hasil penelitian Dian Ratna (2009) terdapat 30,9\% penyesuaian sosial pada siswa dipengaruhi oleh kualitas kehidupan sekolah, dan sisanya $69,1 \%$ dipengaruhi oleh variabelvariabel lain yang tidak diungkap dalam penelitian ini. Sementara itu penelitian Dwi Pratiwi Lestari (2014) menunjukkan bahwa terdapat empat bentuk kesulitan penyesuaian sosial siswa, yaitu (1) kesulitan dalam persahabatan, (2) merasa terasing dalam aktivitas kelompok, (3) kesulitan menghadapi situasi sosial baru, (4) kesulitan memperoleh penyesuaian dalam kelompok.

Berdasarkan fenomena yang telah diuraikan dan hasil penelitian sebelumnya, maka sudah selayaknya sebagai guru BK di sekolah menindaklanjuti permasalahan tersebut. Hal tersebut dikarenakan jika pemahaman siswa tentang penyesuaian sosial rendah maka siswa tidak akan bisa membina hubungan yang baik dengan orang lain, sehingga dengan demikian untuk meningkatkan penyesuaian sosial siswa digunakan layanan informasi dengan pendekatan role playing.

\section{METODOLOGI}

Penelitian ini menggunakan pendekatan kuantitatif. Jenis penelitian ini yaitu penelitian quasi eksperimen jenis The Non Equivalent Control Group. Sekolah yang dipilih dalam penelitian ini adalah SMPN 3 Batusangkar. Subjek penelitian meliputi siswa kelas VII.7 sebagai kelompok eksperimen yang terdiri dari 21 orang siswa dan kelas VII.6 sebagai kelas kontrol yang terdiri dari
22 orang siswa. Teknik pengumpulan data menggunakan kuesioner (angket) dengan skala likert. Setelah data diolah menggunakan rumus statistik kemudian ditetapkan kriteria penilaian masing-masing data yang diperoleh dengan mengacu pada batasan yang dikemukakan oleh Agus Irianto (2004:22), yaitu sebagai berikut.

Tabel 1. Kriteria Pengolahan Data Deskriptif Hasil Penelitian

\begin{tabular}{|c|c|c|}
\hline $\begin{array}{c}\text { Kelas } \\
\text { Interval } \\
\text { Skor } \\
\text { Keseluruhan }\end{array}$ & Kategori & $\begin{array}{c}\text { \% Skor } \\
\text { Keseluruhan }\end{array}$ \\
\hline $134-160$ & Sangat tinggi & $81-100$ \\
\hline $108-133$ & Tinggi & $67-83$ \\
\hline $82-107$ & Sedang & $51-66$ \\
\hline $57-81$ & Rendah & $36-50$ \\
\hline $32-56$ & Sangat rendah & $\leq 31$ \\
\hline
\end{tabular}

Selanjutnya Untuk menguji perbedaan penyesuaian sosial siswa sebelum dan sesudah diberikan perlakuan, dilakukanlah analisis data dengan menggunakan metode $\mathrm{t}$ test. Tulus (2002:87) menyatakan untuk menguji signifikansi perbedaan dua buah mean yang berasal dari dua buah distribusi adalah dengan menggunakan teknik t test dengan rumus sebagai berikut:

t test $=\frac{\bar{X}_{1}-\bar{X}_{2}}{\sqrt{\left[\frac{S D_{1}^{2}}{N_{1}-1}\right]+\left[\frac{S D_{2}^{2}}{N_{2}-1}\right]}}$

Keterangan,

$\bar{X}_{1} \quad$ : Mean tingkat stres akademik siswa unggul.

$\bar{X}_{2} \quad$ : Mean tingkat stres akademik siswa reguler

$S D_{1}^{2} \quad$ : Nilai varian tingkat stres akademik siswa unggul.

$S D_{2}^{2} \quad$ : Nilai varian tingkat stres akademik siswa reguler

$N_{1} \quad$ : Jumlah sampel siswa unggul.

$N_{2} \quad$ : Jumlah sampel siswa reguler.

\section{HASIL}

Berdasarkan hasil penelitian, dapat diungkapkan sebagai berikut.

1. Perbedaan penyesuaian sosial siswa kelompok eksperimen sebelum dan setelah diberi layanan informasi menggunakan pendekatan role playing 
Tabel 2. Hasil pretest dan posttest penyesuaian sosial siswa kelompok eksperimen

\begin{tabular}{|c|l|c|c|c|c|}
\hline \multirow{2}{*}{ Interval } & \multirow{2}{*}{ Kategori } & \multicolumn{2}{|c|}{ Pretest } & \multicolumn{2}{c|}{ Posttest } \\
\cline { 3 - 6 } & & Frekuensi & $\%$ & Frekuensi & $\%$ \\
\hline $134-160$ & $\begin{array}{l}\text { Sangat } \\
\text { tinggi }\end{array}$ & 0 & 0 & 8 & 38.09 \\
\hline $108-133$ & Tinggi & 4 & 19.04 & 12 & 57.14 \\
\hline $82-107$ & Sedang & 15 & 71.42 & 1 & 4.76 \\
\hline $57-81$ & Rendah & 2 & 9.52 & 0 & 0 \\
\hline $32-56$ & $\begin{array}{l}\text { Sangat } \\
\text { rendah }\end{array}$ & 0 & 0 & 0 & 0 \\
\hline \multicolumn{2}{|c|}{ Jumlah } & 21 & 100 & 21 & 100 \\
\hline
\end{tabular}

Berdasarkan Tabel 2 dapat diketahui bahwa terdapat perbedaan penyesuaian sosial siswa pada kelompok eksperimen sebelum dan sesudah mendapat perlakuan layanan informasi dengan menggunakan pendekatan role playing. Pada saat pretest, penyesuaian sosial 4 orang siswa berada pada kategori tinggi dengan persentase sebesar $19.04 \%$, 15 orang siswa berada pada kategori sedang dengan persentase sebesar $71.42 \%$ dan 2 orang siswa berada pada kategori rendah dengan persentase $9.52 \%$. Setelah diberikan perlakuan terjadi perubahan di mana dapat dilihat dari hasil posttest, sebanyak 8 orang siswa berada dalam kategori sangat tinggi dengan persentase sebesar $38.09 \%$, 12 orang siswa berada dalam kategori tinggi dengan persentase sebesar $57.14 \%$ dan 1 orang siswa berada pada kategori sedang dengan persentase $4.76 \%$. Untuk lebih jelasnnya dapat dilihat dari diagram berikut

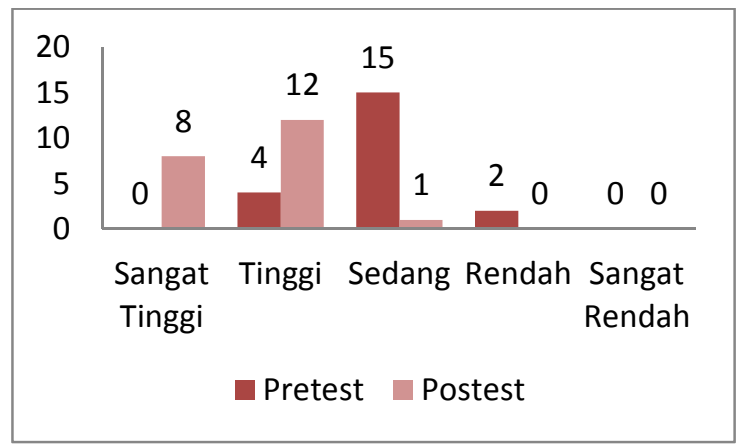

Gambar 1. Diagram distribusi frekuensi pretest dan posstest penyesuaian sosial siswa kelompok eksperimen
Berdasarkan gambar 1 dilihat bahwa terjadinya peningkatan penyesuaian sosial siswa pada kelompok eksperimen sebelum dan sesudah diberikan layanan informasi dengan pendekatan role playing. Dengan demikian dapat disimpulkan bahwa layanan informasi dengan pendekatan role playing efektif untuk meningkatkan penyesuaian sosial siswa di sekolah.

2. Perbedaan penyesuaian sosial siswa kelompok kontrol sebelum dan setelah diberi layanan informasi secara konvensional.

Tabel 3. Hasil pretest dan posttest penyesuaian sosial siswa kelompok kontrol

\begin{tabular}{|c|l|c|c|c|c|}
\hline \multirow{2}{*}{ Interval } & \multirow{2}{*}{ Kategori } & \multicolumn{2}{|c|}{ Pretest } & \multicolumn{2}{c|}{ Posttest } \\
\cline { 3 - 6 } & $\begin{array}{c}\text { Freku } \\
\text { ensi }\end{array}$ & $\%$ & $\begin{array}{c}\text { Freku } \\
\text { ensi }\end{array}$ & $\%$ \\
\hline $134-160$ & $\begin{array}{l}\text { Sangat } \\
\text { tinggi }\end{array}$ & 0 & 0 & 1 & 4.54 \\
\hline $108-133$ & Tinggi & 8 & 36.36 & 9 & 40.90 \\
\hline $82-107$ & Sedang & 10 & 45.45 & 10 & 45.45 \\
\hline $57-81$ & Rendah & 3 & 13.63 & 1 & 4.54 \\
\hline $32-56$ & $\begin{array}{l}\text { Sangat } \\
\text { rendah }\end{array}$ & 1 & 4.54 & 1 & 4.54 \\
\hline \multicolumn{2}{|r|}{ Jumlah } & 22 & 100 & 22 & 100 \\
\hline
\end{tabular}

Berdasarkan Tabel 3 dapat diketahui bahwa terdapat terdapat perbedaan penyesuaian sosial siswa pada kelompok kontrol sebelum dan sesudah mendapat perlakuan layanan informasi konvensional. Pada saat pretest, penyesuaian sosial 8 orang siswa berada pada kategori tinggi dengan persentase sebesar $36.36 \%$, 10 orang siswa berada pada kategori sedang dengan persentase sebesar $45.45 \%, 3$ orang siswa berada pada kategori rendah dengan persentase $13.63 \%$ dan 1 orang siswa berada pada kategori sangat rendah dengan persentase $4.54 \%$. Setelah diberikan perlakuan terjadi perubahan dimana dapat dilihat dari hasil posttest, sebanyak 1 orang siswa berada dalam kategori sangat tinggi dengan persentase sebesar $4.54 \%, 9$ orang siswa berada dalam kategori tinggi dengan persentase sebesar $40.90 \%, 10$ orang siswa berada pada kategori sedang dengan persentase $45.45 \%, 1$ orang siswa berada pada kategori rendah dengan persentase $4.54 \%$ dan 1 orang siswa berada pada kategori sangat rendah dengan persentase $4.54 \%$. Untuk lebih jelasnnya dapat dilihat dari diagram berikut. 


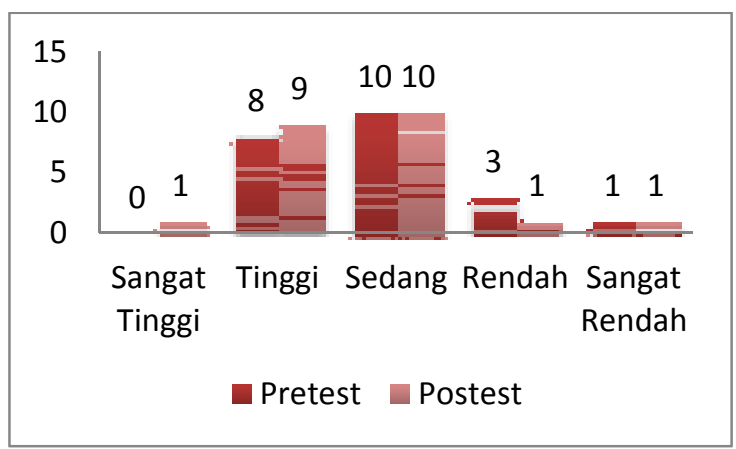

Gambar 2. Diagram Batang Hasil Pretest dan Posstest Kelompok Kentrol

Berdasarkan gambar 2 diketahui bahwa terjadinya peningkatan penyesuaian sosial pada kelompok kontrol sebelum dan sesudah diberikan layanan informasi secara konvensional namun tidak signifikan. Hal ini dapat dilihat pada tabel 3, yaitu masih pada katagori yang sama sebelum dan sesudah diberikan layanan informasi. Dengan demikian dapat disimpulkan bahwa layanan informasi secara konvensional kurang efektif untuk meningkatkan penyesuaian sosial siswa di sekolah.

3. Perbedaan penyesuaian sosial kelompok eksperimen yang diberi layanan informasi dengan pendekatan role playing dengan kelompok kontrol yang diberi layanan informasi secara konvensional.

Tabel 4. Distribusi Frekuensi penyesuaian sosial Siswa Kelompok Eksperimen dan Kelompok Kontrol (Posttest)

\begin{tabular}{|c|c|c|c|c|c|}
\hline \multirow[b]{2}{*}{ Interval } & \multirow[b]{2}{*}{ Kategori } & \multicolumn{2}{|c|}{ Frekuensi } & \multirow[b]{2}{*}{$\mathrm{N}$} & \multirow[b]{2}{*}{$\%$} \\
\hline & & $\begin{array}{c}\text { Eksperi } \\
\text { men }\end{array}$ & Kontrol & & \\
\hline $134-160$ & $\begin{array}{l}\text { Sangat } \\
\text { tinggi }\end{array}$ & 8 & 1 & 9 & 20.93 \\
\hline $108-133$ & Tinggi & 12 & 9 & 21 & 48.83 \\
\hline $82-107$ & Sedang & 1 & 10 & 11 & 25.58 \\
\hline $57-81$ & Rendah & 0 & 1 & 1 & 2.32 \\
\hline $32-56$ & $\begin{array}{l}\text { Sangat } \\
\text { rendah }\end{array}$ & 0 & 1 & 1 & 2.32 \\
\hline \multicolumn{2}{|c|}{ Jumlah } & 21 & 22 & 43 & 100 \\
\hline
\end{tabular}

Berdasarkan Tabel 4 diketahui bahwa dapat dilihat pada kelompok eksperimen, penyesuaian sosial siswa yang berada pada kategori sangat tinggi berjumlah 8 orang, penyesuaian sosial siswa yang berada pada kategori tinggi berjumlah 12 orang dan penyesuaian sosial siswa yang berada pada kategori sedang berjumlah 1 orang. Hasil rata-rata skor posttest penyesuaian sosial siswa pada kelompok eksperimen sebesar 129.9 yang berada pada kategori tinggi. Selanjutnya, pada kelompok kontrol, penyesuaian sosial siswa yang berada pada kategori sangat tinggi berjumlah 1 orang, penyesuaian sosial siswa yang berada pada kategori tinggi berjumlah 9 orang, penyesuaian sosial siswa yang berada pada kategori sedang berjumlah 10 orang dan penyesuaian sosial siswa yang berada pada kategori sangat rendah berjumlah 1 orang Hasil rata-rata skor posttest penyesuaian sosial siswa pada kelompok kontrol sebesar 106.22 yang berada pada kategori sedang. Untuk lebih jelasnnya dapat dilihat dari diagram berikut.

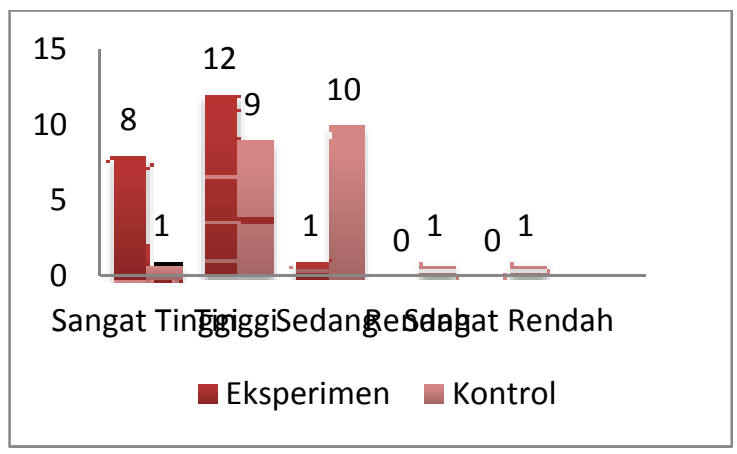

\section{Gambar 3. Diagram hasil posstest kelompok eksperimen dan kelompok kontrol}

Berdasarkan gambar 3 dapat dilihat bahwa terjadinya perbedaan peningkatan penyesuaian sosial siswa pada kelompok eksperimen yang sudah diberikan layanan informasi dengan pendekatan role playing dan kelompok kontrol yang sudah diberikan layanan informasi secara konvensional. Dari diagram pada gambar 5 dapat disimpulkan layanan informasi dengan pendekatan role playing lebih efektif dalam meningkatkan penyesuaian sosial siswa daripada layanan informasi yang diberikan secara konvensional.

\section{PEMBAHASAN}

1. Perbedaan penyesuaian sosial siswa kelompok eksperimen sebelum dan sesudah diberi layanan informasi dengan pendekatan role playing

Berdasarkan pengujian hipotesis pertama, dapat disimpulkan bahwa terdapat perbedaan yang signifikan pada penyesuaian sosial siswa kelompok 
eksperimen sebelum dan sesudah diberi layanan informasi dengan menggunakan pendekatan role playing. Hal ini dapat dilihat dari nilai Asymp. Sig.(2-tailed) yang lebih kecil dari taraf signifikansi $0.05 \quad(0.000<0.05)$. Penyesuaian sosial yang dimaksudkan dalam penelitian ini adalah kemampuan individu dalam membina hubungan dengan orang lain, bekerja sama dengan orangorang sekitar, memiliki tanggung jawab dan menghargai pendapat orang lain supaya memuaskan untuk dirinya dan untuk orang lain. Pemahaman tersebut diperoleh melalui layanan informasi dengan menggunakan pendekatan role playing.

Penyesuaian sosial sangat penting dimiliki oleh semua siswa karena proses adaptasi bagi seseorang individu dengan lingkungan di sekolahnya, baik dengan teman sebaya, guru, tata usaha, serta lingkungan sekolah secara umum. Memberikan pemahaman kepada siswa mengenai penyesuaian sosial merupakan salah satu cara yang dapat memperbaiki penyesuaian sosial seseorang. Hal ini dimaksudkan agar seseorang individu bisa memiliki penyesuaian sosial yang baik di dalam berhubungan dengan orang lain. Dengan demikian, cara peneliti untuk meningkatkan penyesuaian sosial siswa adalah dengan cara memberikan layanan informasi dengan pendekatan role playing.

Layanan informasi adalah salah satu komponen dalam program bimbingan dan konseling yang membekali peserta didik dengan pengetahuan tentang data dan fakta di bidang pendidikan di sekolah, bidang pekerjaan, bidang perkembangan sosial, dan pribadi, agar peserta didik lebih mampu mengatur dan merencanakan kehidupannya sendiri (Prayitno, 2004:36). Layanan informasi juga memberikan pemahaman kepada individu tentang berbagai hal yang diperlukan untuk menguasai suatu tugas atau kegiatan untuk menentukan arah suatu tujuan atau rencana yang dikehendaki.

Pada penelitian ini, pendekatan role playing yang dilaksanakan adalah dengan membagi siswa ke dalam dua kelompok yang setiap kelompoknya terdiri dari sepuluh sampai sebelas orang. Peneliti menjelaskan tata cara di dalam melaksanakan bermain peran. Setelah itu setiap kelompok diberi kesempatan untuk mendiskusikan peran yang akan dimainkannya. Setelah selesai didiskusikan, kelompok memperagakan perannya masing-masing. Setelah itu menilai bagaimana tampilan dari kelompok yang memerankan perannya itu. Dalam penggunaan pendekatan pembelajaran ini tak hanya menjadikan siswa aktif, melainkan menjadikan siswa lebih menguasai peran-peran yang dimainkannya.
Keefektifan pemberian layanan informasi dengan pendekatan role playing diperkuat dengan hasil temuan pada hipotesis pertama yang menyatakan bahwa terdapat perbedaan yang signifikan pada penyesuaian sosial siswa kelompok eksperimen sebelum dan sesudah diberi layanan informasi dengan pendekatan role playing. Hal ini ditunjukkan dengan adanya peningkatan hasil ratarata skor kelompok eksperimen.

Berdasarkan hal yang telah dijelaskan di atas, maka layanan informasi dengan pendekatan role playing efektif diberikan dalam rangka meningkatkan penyesuaian sosial siswa. Dengan adanya layanan informasi dengan pendekatan role playing, menjadikan siswa lebih memiliki pemahaman tentang penyesuaian sosial yang baik.

2. Tidak terdapat perbedaan penyesuaian sosial siswa kelompok kontrol sebelum dan sesudah diberi layanan informasi secara konvensional

Pemberian layanan informasi untuk meningkatkan penyesuaian sosial siswa dapat dilakukan dengan cara konvensional. Dari hasil perhitungan hipotesis diperoleh nilai Asymp. Sig.(2tailed) lebih besar dari taraf signifikansi 0.05 $(0.521>0.05)$. Dengan demikian, hipotesis kedua pada penelitian ini dapat diterima, di mana tidak terdapat perbedaan yang signifikan pada penyesuaian sosial siswa kelompok kontrol secara konvensional.

Dikatakan tidak signifikan karena hanya terjadi perbedaan mean sebelum dan sesudah diberi perlakukan, sementara tidak terjadinya perbedaan katagori. Layanan informasi dalam meningkatkan penyesuaian sosial siswa kelompok kontrol diberikan secara konvensional, yaitu teknik ceramah dan tanya jawab. Senada dengan pernyataan tersebut, metode atau teknik yang digunakan dalam penyajian layanan informasi menurut Prayitno (2012:97) adalah penyajian dan tanya jawab.

Pemberian layanan informasi secara konvensional ini menyajikan materi yang sama diberikan pada kelas eksperimen. Materi penyesuaian sosial yang diberikan meliputi pentingnya kerja sama, membina hubungan baik dengan teman, tanggung jawab dan menghargai pendapat orang lain. Dalam hal ini hanya terdapat perbedaan motode dan pendekatan pembelajaran selama proses belajar.

Kurang efektifnya layanan informasi yang diberikan secara konvensional terlihat dari penggunaan waktu saat proses pembelajaran. Banyaknya materi yang dibahas setiap kali 
pertemuan membuat rendahnya motivasi siswa dalam belajar dan membuat siswa jenuh dalam belajar. Karena pembelajaran secara konvensional menjadikan guru yang lebih aktif. Pembelajaran yang monoton ini pula yang menyebabkan siswa banyak melakukan aktivitas lain selain materi pelajaran yang diajarkan. Adanya perilaku mengganggu teman, bermain game online, keluar dan masuk kelas menjadi tradisi bagi siswa yang malas belajar. Selain itu hal tersebut juga diindikasikan rendahnya pengetahuan dan kemampuan siswa dalam menerima pelajaran. Pada hasil penelitian ini tergambarlah bahwa kurang efektifnya pembelajaran secara konvensional pada layanan informasi dengan materi penyesuaian sosial. Hal ini di dukung dengan hasil penelitian yaitu tidak adanya perubahan katagori pada sebelum dan sesudah diberikan layanan.

\section{Perbedaan penyesuaian sosial kelompok eksperimen yang diberi layanan informasi dengan pendekatan role playing dengan kelompok kontrol yang diberi layanan penguasaan konten secara konvensional}

Tujuan dari penelitian ini adalah untuk melihat perbedaan efektivitas layanan informasi dengan pendekatan role playing pada kelompok eksperimen dan layanan penguasaan konten konvensional pada kelompok kontrol dalam meningkatkan penyesuaian sosial siswa. Hasil penelitian menunjukkan bahwa terdapat perbedaan yang signifikan pada penyesuaian sosial kelompok eksperimen yang diberi layanan informasi dengan pendekatan role playing dengan kelompok kontrol yang diberi layanan informasi konvensional. Penyesuaian sosial yang dimaksudkan dalam penelitian ini adalah proses adaptasi seseorang individu dengan lingkunganya, sehingga individu tersebut dapat diterima dan berada dalam lingkunyan tersebut. Orang yang berhasil melakukan penyesuaian sosial dengan baik mengembangkan sikap sosial yang menyenangkan seperti kesediaan membantu orang lain meskipun mereka sendiri mengalami kesulitan, mereka tidak terkait pada diri sendiri.

Untuk melihat perbedaan penyesuaian sosial pada masing-masing kelompok, diberikan posttest sesudah pemberian perlakuan selesai. Hasil posttest kelompok eksperimen menunjukkan penyesuaian sosial siswa yang berada pada kategori sangat tinggi berjumlah 8 orang, penyesuaian sosial siswa yang berada pada kategori tinggi berjumlah 12 orang dan penyesuaian sosial siswa yang berada pada kategori sedang berjumlah 1 orang. Hasil rata-rata skor posttest penyesuaian sosial siswa pada kelompok eksperimen sebesar 129.9 yang berada pada kategori tinggi.
Selanjutnya, pada kelompok kontrol, penyesuaian sosial siswa yang berada pada kategori sangat tinggi berjumlah 1 orang, penyesuaian sosial siswa yang berada pada kategori tinggi berjumlah 9 orang, penyesuaian sosial siswa yang berada pada kategori sedang berjumlah 1 orang dan penyesuaian sosial siswa yang berada pada kategori sangat rendah berjumlah 1 orang Hasil rata-rata skor posttest penyesuaian sosial siswa pada kelompok kontrol sebesar 106.22 yang berada pada kategori sedang.

Berdasarkan hasil uji statistik juga menunjukkan adanya perbedaan penyesuaian sosial pada kelompok eksperimen dan kelompok kontrol. Hasil pengujian dengan teknik uji t-test memperlihatkan koefisien $t_{\text {hitung }}$ sebesar 4.899. Dari hasil perhitungan tersebut diperoleh nilai Asymp. Sig.(2-tailed) lebih kecil dari taraf signifikansi 0.05 $(0.000<0.05)$. Hal ini menandakan terdapat perbedaan yang signifikan penyesuaian sosial kelompok eksperimen yang diberi layanan informasi dengan pendekatan role playing dengan kelompok kontrol yang diberi layanan informasi konvensional.

Selanjutnya, untuk menentukan kelompok mana yang mengalami peningkatan lebih tinggi pada penyesuaian sosial siswa, dapat melihat besarnya rata-rata skor pada masing-masing kelompok. Rata-rata skor penyesuaian sosial siswa kelompok eksperimen lebih tinggi dibandingkan dengan rata-rata skor penyesuaian sosial siswa kelompok kontrol, di mana rata-rata skor kelompok eksperimen sebesar 129.9 dan rata-rata skor kelompok kontrol sebesar 106.22. Dengan demikian, kelompok eksperimen mengalami peningkatan penyesuaian sosial yang lebih tinggi dibandingkan dengan kelompok kontrol.

Perbedaan penyesuaian sosial siswa terjadi karena adanya perbedaan perlakuan yang diterima oleh masing-masing kelompok, walaupun materi dan banyaknya perlakuan yang diberikan samasama berjumlah 4 kali. Kelompok eksperimen diberikan perlakuan layanan informasi dengan pendekatan role playing, sementara kelompok kontrol diberikan perlakuan layanan informasi konvensional.

Pada kelompok eksperimen pemberian layanan informasi dengan pendekatan role playing dilakukan dengan membagi kelas menjadi dua kelompok, menjelaskan dan memberikan pemahaman kepada siswa mengenai topik yang diberikan di dalam menjalankan perannya masingmasing. 
Pendekatan role playing menggambarkan salah satu pendekatan pembelajaran aktif, inovatif, kreatif, dan menyenangkan. Selanjutnya, pada kelompok kontrol diberikan perlakuan berbeda dari kelompok eksperimen yaitu pemberian layanan informasi secara konvensional. Pemberian layanan informasi secara konvensional ini dilakukan secara klasikal. Peneliti memberikan materi-materi mengenai penyesuaian sosial dengan teknik ceramah dan tanya jawab. Setelah peneliti memberikan materi dengan teknik ceramah, kemudian peneliti mempersilahkan siswa untuk bertanya apabila terdapat hal yang belum dipahami. Sebelum menjawab beberapa pertanyaan yang dilontarkan siswa, pertanyaan tersebut terlebih dahulu dilemparkan ke forum dengan tujuan agar siswa-siswa yang lain juga ikut berpikir mengenai pertanyaan yang telah dikemukakan.

Selama proses pembelajaran berlangsung, tidak banyak siswa yang merespon pertanyaan dari peneliti atau siswa yang lain. Siswa yang aktif biasanya selalu sama pada setiap pertemuan, dan sulit untuk mendorong siswa lain untuk ikut aktif dengan teknik ceramah yang digunakan. Berdasarkan penilaian segera dengan BMB3 banyak siswa yang masih malas mengemukakan pendapatnya dan lebih terlihat jenuh dan juga terlihat siswa yang kurang serius dan sibuk dengan urusannya masing-masing.

\section{KESIMPULAN DAN SARAN}

\section{a. Kesimpulan}

Secara khusus temuan dalam penelitian ini adalah sebagai berikut.

1. Terdapat perbedaan yang signifikan pada penyesuaian sosial siswa kelompok eksperimen sebelum dan sesudah diberi layanan informasi dengan pendekatan role playing.

2. Tidak terdapat perbedaan yang signifikan pada penyesuaian sosial siswa kelompok kontrol sebelum dan sesudah diberi layanan informasi secara konvensional.

3. Terdapat perbedaan yang signifikan antara penyesuaian sosial kelompok eksperimen yang diberi layanan informasi dengan pendekatan role playing dengan kelompok kontrol yang diberi layanan informasi secara konvensional.

\section{b. Saran}

Berdasarkan hasil penelitian maka peneliti menyarankan bagi guru BK atau konselor untuk memprogramkan penyelenggaraan layanan informasi secara berkesinambungan sesuai dengan kebutuhan siswa. Tentunya pelaksanaan layanan informasi dapat disesuaikan dengan berbagai strategi pembelajaran, tidak hanya secara konvensional saja. Bagi kepala sekolah diharapkan untuk untuk lebih memperhatikan pelaksanaan layanan bimbingan dan konseling di sekolah, terutama dalam penyediaan dan pengadaan sarana dan prasarana yang diperlukan guru BK dalam melaksanakan pelayanan bimbingan dan konseling kepada siswa dan terus mendukung program guru bimbingan dan konseling, untuk meningkatkan kualitas guru bimbingan dan konseling/konselor dengan lebih banyak lagi. Bagi peneliti lainnya perlu dilakukan penelitian yang berkaitan dengan penyesuaian sosial siswa dengan studi lanjutan dan penggunaan strategi pembelajaran lainnya, latar belakang munculnya dan upaya pengentasannya. Selain itu hasil penelitian ini juga dapat digunakan panduan bagi penggunaan layanan bimbingan dan konseling baik secara klasikal maupun secara kelompok.

\section{KEPUSTAKAAN}

Agus Irianto. 2004. Statistik Konsep Dasar, Aplikasi dan Pengembangannya. Jakarta: Renada Mendia Group.

Ahmad Yanizon. 2012. "Peningkatan Penyesuaian Sosial Siswa melalui Layanan Bimbingan Kelompok (Studi Eksperimen di Madrasah Aliyah Negeri 1 Curup)". Tesis tidak diterbitkan. Padang: Program Pascasarjana UNP Padang.

Dian Ratna. 2009. Hubungan Kualitas Kehidupan Sekolah dengan Penyesuaian Sosial pada Siswa SMA Internasional Islamic Boarding School Republic Of Indonesia. Jurnal Psychoidea . ISSN 1693-1076. Diakses pada tanggal 23 Februari 2016.

Dwi Pratiwi. 2014. Bimbingan dan Konseling Pribadi dalam Mengatasi Penyesuaian Sosial Siswa MTs Negeri 1 Yogyakarta. Tesis. UIN Sunan Kalijaga. Dalam http://ejournal.ikippgrimadiun.ac.id/index.php $\underline{\mathrm{K} / \text { article/view/565. }}$. diakses pada tanggal 23 Februari 2016.

Hurlock, Elizabeth B. 1993. Perkembangan Anak Jilid 1. Jakarta: Erlangga.

Istarani. 2012. 58 Model Pembelajaran Inovatif. Medan: Media Persada

Nova Erianti. 2011. Masalah-masalah Hubungan Sosial Siswa dalam Belajar. Skripsi Tidak Diterbitkan. 
Prayitno. 2004. Seri Layanan Konseling (L1-L9). Padang: BK FIP UNP.

Prayitno. 2006. Dasar-Dasar Bimbingan dan Konseling. Jakarta: Rineka Cipta.

Prayitno. 2009. Wawasan Profesional Konseling. Padang: FIP UNP.

Prayitno. 2012. Jenis Layanan dan Kegiatan Pendukung Konseling. Padang: BK FIP UNP.

Tulus Winarsunu. 2002. Statistik dalam Penelitian Psikologi dan Pendidikan. Malang: UMM Press. 